\title{
Anti-proliferation potential and content of fucoidan extracted from sporophyll of New Zealand Undaria pinnatifida
}

\author{
Wilfred Mak ${ }^{1}$, Sheng Kelvin Wang ${ }^{1}$, Tingting Liu ${ }^{1}$, Nazimah Hamid ${ }^{1,2}$, Yan Li $^{2,3}$, Jun Lu ${ }^{1,2,3,4}$ and \\ William Lindsey White ${ }^{1,2,3}$
}

\footnotetext{
School of Applied Sciences, Faculty of Health and Environmental Sciences, Auckland University of Technology, Auckland, New Zealand

2 Institute for Applied Ecology New Zealand, Faculty of Health and Environmental Sciences, Auckland University of Technology, Auckland, New Zealand

${ }^{3}$ School of Interprofessional Health Studies, Faculty of Health and Environmental Sciences, Auckland University of Technology, Auckland, New Zealand

${ }^{4}$ Institute of Biomedical Technology, Auckland University of Technology, Auckland, New Zealand
}

\section{Edited by:}

António Manuel Peres, Instituto

Politécnico de Bragança, Portugal

Reviewed by:

Susana Maria Cardoso, Polytechnic

Institute of Coimbra, Portugal

Isabel C. F. R. Ferreira, Instituto

Politécnico de Bragança, Portugal

${ }^{*}$ Correspondence:

Jun Lu, Faculty of Health and

Environmental Sciences, School of

Applied Sciences, Auckland University

of Technology, 34 St Paul Street,

Auckland 1142, New Zealand

e-mail: jun.lu@aut.ac.nz
Undaria pinnatifida is a species of brown seaweed known to contain rich amounts of fucoidan, a sulfated polysaccharide known to possess various biological activities. We isolated crude fucoidan (F0) from the sporophylls of U. pinnatifida grown in the Marlborough Sounds, New Zealand. Sulfate content, uronic acid content, and molecular weight of F0 were $15.02,1.24$, and $>150 \mathrm{kDa}$, respectively. F0 was fractionated to yield three further fractions: F1, F2, and F3. Cytotoxicity of two major fractions was determined by the 3(4,5-dimethylthiazol-2-yl)-2,5-diphenyltetrazolium bromide (MTT) assay. The algal fucoidans specifically suppressed the proliferation of three cancer cell lines with less cytotoxicity against the normal cells. Selective cytotoxicity could relate to the distinctive structures of each fucoidan fraction. Results from this study provide evidence that fucoidan, especially from U. pinnatifida grown in New Zealand, possesses great potential to be used as a functional food to reduce cancer risk or supplement cancer treatment.

\section{INTRODUCTION}

Fucoidan is a group of sulfated heteropolysaccharide commonly found in brown seaweeds (1). They are composed primarily of $\mathrm{L}$-fucose residues, and sulfate groups with smaller amounts of D-galactose, D-mannose, D-xylose, D-glucose, uronic acids, and protein (2). Numerous fucoidan types may coexist in the sporophyll of the same algae and their composition varies between species of brown seaweed (3). Since its first isolation from brown seaweed in 1913 (4), fucoidan has been extensively studied. Due to the popularity and increase in demand of pharmaceutical drugs derived from natural sources, it was not until the last decade or so have researchers focused more on the polysaccharides' broad range of physiological and biological activities $(5,6,7)$. These include beneficial cytotoxicity (1), anti-inflammatory (8), antiviral (9), antioxidant (10), and anticoagulant activities (1). As a result, fucoidans have great potential use in the production of new therapeutic agents in the diagnosis and treatment of human diseases. Consequently, research in this area and their cytotoxicity was investigated. Previous studies have also showed that these biological activities were thought to be influenced by their degree of sulfation (11), molecular mass (12), as well as the fucose:sulfate molar ratio (13).

Cancer is a serious disease with complex pathological pathways in the human body. The implementation of natural anticancer agents has been recognized as a possible alternative to conventional chemotherapeutic agents that are associated with minimal survival rates and unpleasant side effects (14). Fucoidan was reported to suppress the growth of cancer cells in vivo, and enhances the immune system to subdue the development of tumors (15).
Fucoidan was reported to induce a reduction in some types of human cancer cell lines in a dose-dependent manner $(16,17)$, and clinical trials of fucoidan ingested in human subjects had given promising results (18). However, more research is required in order to promote the use of fucoidan for potential chemotherapeutic treatments. Sulfate content and molecular weight $(\mathrm{Mw})$ of fucoidan polymers have been reported to have a direct relationship to fucoidans' cytotoxicity and because fucoidan is a polymer mixture, fucoidans extracted from different seaweed or different locations have different bioactivity (19). However, cytotoxicity of lower and higher Mw fucoidans have not been investigated $(11,19)$.

Undaria pinnatifida is a brown seaweed native to Japan, China, and Korea (20) where it is also commercially cultivated for food production (21). It has now spread to over twelve countries including France, Spain, Italy, Argentina, North and South America, Australia, and New Zealand. Their ability to grow in a range of habitats made $U$. pinnatifida an unwanted organism in New Zealand, and was therefore illegal to harvest $U$. pinnatifida commercially (20). Hence structural information on fucoidan from New Zealand $U$. pinnatifida has not been reported. Few studies have been carried out to investigate the anticancer activity of fucoidan extracted from $U$. pinnatifida $(11,16,19)$. In particular, knowledge on the bioactivity of fucoidan from New Zealand brown seaweed on human cancer cell lines was absent. Hence the present study was undertaken to first characterize the chemical composition of fucoidan from New Zealand U. pinnatifida. Crude fucoidan (F0) was then purified using anion-exchange chromatography to yield three fractions (F1, F2, and F3), and their cytotoxicity were investigated against MCF-7 (breast adenocarcinoma cell line), A-549 
(lung carcinoma cell line), WiDr (colon adenocarcinoma cell line), Malme-3M (lung melanoma cell line), HEK-293 (human embryonic kidney cell line), LoVo (human colon adenocarcinoma cell line), HUVEC (Human Umbilical Vein Endothelial Cell line), and HDFb (Human Derma Fibroblast cell line) cells using the 3-(4, 5dimethylthiazol-2-yl)-2, 5-diphenyl tetrazolium bromide (MTT) cell proliferation assay in comparison with commercial fucoidan (Sigma, USA). The relationship between cytotoxicity and chemical composition was also examined and discussed.

\section{MATERIALS AND METHODS MATERIALS}

Undaria pinnatifida was harvested from Port Underwood, New Zealand in September 2011 from two selected mussel farms (farms 106 and 327). The two seaweed samples were independently prepared for extraction. The sporophyll and blade were separated into labeled bags and lyophilized (Christ LOC 1-M Alpha 2-4, Martin Christ, Osterode am Harz, Germany) in bulk within $48 \mathrm{~h}$ of frozen storage. The dried sample was milled using a coffee grinder (Breville CG2B), sieved $(<0.6 \mathrm{~mm})$ and then stored in PET containers at room temperature before analyses (22). All chemicals and reagents were of analytical grade.

\section{EXTRACTION OF FUCOIDAN}

Crude fucoidan was extracted as described previously (13). Each extraction was carried out using sporophylls from separate plants harvested in September, 2011. Four replicate samples of dried algal biomass $(15 \mathrm{~g}$ ) was treated at room temperature for $24 \mathrm{~h}$ with a $\mathrm{MeOH}-\mathrm{CHCl}_{3}$-water mixture (4:2:1) to remove lipids, protein, and colored pigments. The treated algal biomass was filtered through a Whatman's filter paper $(90 \mathrm{~mm}$ GF/D), then washed with acetone and dried overnight at room temperature. Treated algae $(10 \mathrm{~g})$ were mechanically stirred with $2 \%$ aqueous $\mathrm{CaCl}_{2}(100 \mathrm{~mL})$ at $85^{\circ} \mathrm{C}$ for $5 \mathrm{~h}$. The extract was centrifuged at $18500 \mathrm{~g}$ (Eppendorf Centrifuge 5810R V3.1, Eppendorf AG, Hamburg, Germany) and the supernatant was collected. A hexadecyltrimethylammonium bromide (cetavlon) solution (10\%, $50 \mathrm{~mL}$ ) was added to the extract and was left to precipitate at $4^{\circ} \mathrm{C}$ overnight. The precipitate was centrifuged at $18500 \mathrm{~g}$, washed with water and mechanically stirred with $60 \mathrm{~mL}$ ethanolic $\mathrm{NaI}$ solution (20\%) for $72 \mathrm{~h}$. The precipitate was removed by centrifugation, washed with ethanol and lyophilized (Christ LOC 1-M Alpha 2-4, Martin Christ, Osterode am Harz, Germany) to give crude fucoidan (23).

\section{DETERMINATION OF SULFATE, URONIC ACID, AND PROTEIN CONTENT}

Sulfate content was quantified using the $\mathrm{BaCl}_{2}$-gelatin method using $\mathrm{K}_{2} \mathrm{SO}_{4}$ as the standard after hydrolyzing fucoidan $(15 \mathrm{mg})$ in $4 \mathrm{M} \mathrm{HCl}$ for $2 \mathrm{~h}$ at $100^{\circ} \mathrm{C}(24)$. Uronic acid and protein content of fucoidan were determined using the carbazole-sulfuric acid-borate reaction using D-glucuronic acid as the standard (25), and the Bradford assay using bovine serum albumin as the standard (26), respectively. Absorbance measurements were recorded using an Ultrospec $2100 \mathrm{UV} /$ visible spectrophotometer. Experiments were performed in triplicates as three independent assays. All yields were calculated from the dried weight of fucoidan and converted to a percentage.

\section{FRACTIONATION OF FUCOIDAN}

Crude fucoidan was purified by fractionation using anionexchange chromatography. Crude fucoidan $(2 \mathrm{~g})$ was dissolved in $20 \mathrm{~mL}$ of Tris- $\mathrm{HCl}$ buffer $(0.05 \mathrm{M}, \mathrm{pH} 7.4)$ and applied to a column $(25 \mathrm{~cm} \times 4 \mathrm{~cm})$ of DEAE-Sephadex A-25 (Pharmacia Ltd.) equilibrated with Tris-HCl buffer connected to a Bio-Rad 2110 fraction collector. The first fraction was eluted with deionized water at a flow rate of 40 drops per tube, followed by $\mathrm{NaCl}$ elution at increasing concentrations ( 1 and $2 \mathrm{M}$ ) until the absence of a positive reaction for the presence of sugars in the test tubes when using the phenol-sulfuric acid method according to Dubois et al. (27). Briefly, test tubes containing the eluted samples were transferred $(1 \mathrm{~mL})$ into more robust glass test tubes $(5 \mathrm{~mL})$. Then $0.05 \mathrm{~mL} 80 \%$ phenol and $2.5 \mathrm{~mL}$ concentrated $\mathrm{H}_{2} \mathrm{SO}_{4}$ were added to each test tube and mixed thoroughly. Test tubes were placed on a rack and heated in a $35^{\circ} \mathrm{C}$ water bath for $20 \mathrm{~min}$. The absorbance was measured at $480 \mathrm{~nm}$ (Ultrospec 2100) for any indication of sugars and uronic acids (27). Each carbohydratepositive fraction was pooled together, dialyzed for $72 \mathrm{~h}$ (MWCO $12-14,000)$ in deionized water with a water change daily and then lyophilized.

\section{DETERMINATION OF MONOSACCHARIDE COMPOSITION}

Monosaccharides were analyzed by gas chromatography of their alditol acetate derivatives (28). Fucoidan (10 mg) was hydrolyzed in $0.5 \mathrm{~mL}$ of $2 \mathrm{M}$ trifluoroacetic acid at $121^{\circ} \mathrm{C}$ in sealed glass tubes flushed with nitrogen for $4 \mathrm{~h}$. After cooling to room temperature, $25 \mu \mathrm{L}$ of $20 \mathrm{mg} / \mathrm{mL}$ allose was added as an internal reference. The hydrolyzate was filtered through a $0.2 \mu \mathrm{m}$ PhenexRC syringe filter into clean glass tubes and evaporated to dryness with a gentle stream of filtered air. Milli-Q water $(100 \mu \mathrm{L})$ was added to the dried hydrolyzates and incubated at $40^{\circ} \mathrm{C}$ for $90 \mathrm{~min}$ after the addition of $20 \mu \mathrm{L}$ of $15 \mathrm{M}$ ammonia and $1 \mathrm{~mL}$ of $0.5 \mathrm{M}$ sodium borohydride in dimethyl-sulfoxide (DMSO). After cooling to room temperature, 1 -methylimidazole $(200 \mu \mathrm{L})$ and acetic anhydride $(2 \mathrm{~mL})$ was added to the mixture and incubated for a further $10 \mathrm{~min}$. Milli-Q water $(5 \mathrm{~mL})$ was added into each tube to neutralize the excess acetic anhydride and allowed to cool to room temperature. Alditol acetates were extracted by the addition of $1 \mathrm{~mL}$ dichloromethane (DCM), and the lower DCM phase was transferred using a Pasteur pipette into a clean glass test tube. This extraction was repeated once more. The combined DCM extracts was washed with $4 \mathrm{~mL}$ Milli-Q water and the upper water phase was discarded. The wash was repeated twice more. Alditol acetates were analyzed by GC (GC-2010, Shimadzu) using a ZB-5 capillary column $(30 \mathrm{~mm} \times 0.25 \mathrm{~mm})$ coupled to a flame ionization detector. The detector temperature was held at $280^{\circ} \mathrm{C}$ while the injector temperature was set at $240^{\circ} \mathrm{C}$. Nitrogen was used as the carrier gas at a flow rate of $1.5 \mathrm{~mL} / \mathrm{min}$ and a split ratio of 10. The oven temperature was set at $38^{\circ} \mathrm{C}$ for $1 \mathrm{~min}$, increased to $200^{\circ} \mathrm{C}$ at $50^{\circ} \mathrm{C} / \mathrm{min}$, further increased to $210^{\circ} \mathrm{C}$ at $2^{\circ} \mathrm{C} / \mathrm{min}$, and then held for $5 \mathrm{~min}$ at the final temperature. Sugar standards used were: L (- )-fucose (Sigma, USA), D (+)-galactose (Serva, Germany), D(+)-xylose (Sigma, USA), D (+)-mannose (Sigma, USA), $\alpha$-D $(+)$-glucose (Sigma, USA), and $\beta$-D-allose (Sigma, USA). Preparations of sugar standards to their alditol acetate derivatives were identical to that of crude fucoidan. Due to limited resources 
from farm 106, only U. pinnatifida from farm 327 was analyzed for monosaccharide content.

\section{DETERMINATION OF AVERAGE MOLECULAR WEIGHT}

Average Mw of fucoidan from the sporophylls of $U$. pinnatifida was determined by gel permeation chromatography (GPC) using a Sephadex G-100 column $(25 \mathrm{~cm} \times 4 \mathrm{~cm})$ equilibrated with phosphate buffer (Bio-Lab Ltd.) (10 mM, pH 7). Crude fucoidan, its fractions (F1, F2, and F3), and commercial fucoidan (10 mg each) were dissolved in $1 \mathrm{~mL}$ phosphate buffer and applied to the column at a flow rate of 40 drops per tube. Presence of sugars was detected using the phenol-sulfuric acid method (27). Dextrans (12, 25, 50, $80,150 \mathrm{KDa})$ purchased from Sigma were used as standard Mw markers. Blue Dextran 2000 (Pharmacia, Sweden) was used as a void volume marker.

\section{CELL REDUCING CAPACITY (CYTOTOXICITY) ASSAY}

A-549 cells (lung carcinoma cell line, ATCC CCL-185 ${ }^{\mathrm{TM}}$ ), WiDr cells (colon adenocarcinoma cell line, ATCC CCL-218 ${ }^{\mathrm{TM}}$ ), MCF-7 cells (breast adenocarcinoma cell line, ATCC HTB-22 ${ }^{\mathrm{TM}}$ ), Malme$3 \mathrm{M}$ cells (lung melanoma cell line, ATCC HTB-64 ${ }^{\mathrm{TM}}$ ), HEK-293 cells (human embryonic kidney cell line, ATCC CRL-1573 ${ }^{\mathrm{TM}}$ ), HUVEC cells (human umbilical vein endothelial cell line, ATCC PCS-100-010 ${ }^{\mathrm{TM}}$ ), LoVo cells (human colon adenocarcinoma cell line, ATCC CCL-229 ${ }^{\mathrm{TM}}$ ), and HDFb cells (human derma fibroblast cell line, Invitrogen NZ Limited) were each cultured in $5 \mathrm{~mL}$ of Roswell Park Memorial Institute 1640 (RPMI 1640) complete medium (GIBCO, USA) supplemented with 1\% PenicillinStreptomycin (Invitrogen, USA), 1\% L-glutamine (Invitrogen, USA) and $10 \%$ fetal bovine serum (Medica Pacifica, USA) at $37^{\circ} \mathrm{C}$ in a $5 \% \mathrm{CO}_{2}$ atmosphere.

The cytotoxicity/cell reducing capacity of crude fucoidan (F0) and its fractions (F1 and F3) was determined using the MTT cell proliferation assay (29). Each cell line (A-549, WiDr and MCF-7) was sub-cultured $(100 \mu \mathrm{L})$ in 96 -well plates at a density of $1 \times 10^{5}$ cells per well and allowed to attach to the well bottom for $24 \mathrm{~h}$ in $5 \% \mathrm{CO}_{2}$ at $37^{\circ} \mathrm{C}$. Different concentrations $\left(0.2-1.0 \mathrm{mg} \mathrm{mL}^{-1}\right)$ of crude fucoidan (F0), its fractions (F1 and F3), and commercial fucoidan (Fucus vesiculosus, Sigma, USA) were added into the wells $(100 \mu \mathrm{L})$ and were incubated for a further $24 \mathrm{~h}$. The supernatant was removed and washed with $150 \mu \mathrm{L}$ of PBS (pH 7.2) and removed again. The plates were re-incubated for $4 \mathrm{~h}$ after the addition of $30 \mu \mathrm{L}$ of MTT ( $5 \mathrm{mM}$, in phosphate buffered saline solution at $\mathrm{pH}$ 7.2) reagent and a further $30 \mathrm{~min}$ after adding $150 \mu \mathrm{L}$ of DMSO. Absorbance of each well was measured at $540 \mathrm{~nm}$ using a FLUOstar Omega microplate reader (Alphatech, New Zealand). Assays were performed after treatment of cells for 24,48 , and $72 \mathrm{~h}$. The data were used to calculate the cell viability percentage using the equation below. The $\mathrm{IC}_{50}$ value was calculated using Prism 5 (GraphPad Software Inc., San Diego, CA, USA).

$$
\begin{aligned}
& \text { Cell Viability (\%) } \\
& \qquad\left(\begin{array}{c}
(\text { Abs of control }- \text { Abs of blank }) \\
-(\text { Abs of sample }- \text { Abs of blank }) \\
(\text { Abs of control }- \text { Abs of blank })
\end{array}\right) \times 100
\end{aligned}
$$

\section{STATISTICAL ANALYSIS}

Analysis of variance (ANOVA) was carried out using Minitab ${ }^{\circledR}$ (Version 15) to test for differences between fucoidan fractions. Results of all tests were considered significant if $p<0.05$. Where significant differences occurred, the Tukey's Honest Significance Difference (HSD) test was employed to examine where that effect occurred.

\section{RESULTS \\ CRUDE FUCOIDAN YIELD AND CHEMICAL COMPOSITION}

Crude fucoidan was extracted from the sporophylls of New Zealand $U$. pinnatifida by $\mathrm{CaCl}_{2}$ extraction. Yield of sporophyllderived fucoidan were $69.98 \pm 0.99 \%$ and $57.28 \pm 6.18 \%$ dry weight from farms 327 and 106, respectively. Sporophyll-derived fucoidan contained 7.9 times more fucoidan from site 327 than U. pinnatifida harvested in the Kyoungbuk province, Korea while site 106 was 6.5 times more although the extraction method between the two studies was different (19). However, yields of sporophyll-derived crude fucoidan from both sites were slightly lower compared to $71.50 \%$ yield previously reported from Sargassum wightii collected along the coast of Gulf of Mannar, India (30). As shown in Table 1, crude fucoidan (F0) was shown to be composed primarily of fucose $(39.24 \%)$, xylose $(28.85 \%)$, galactose $(26.48 \%)$, and sulfate $(15.02 \%)$. The minor components were made up of mannose $(5.04 \%)$, glucose $(0.95 \%)$, uronic acid $(1.24 \%)$, and protein $(0.36 \%)$. A sample chromatogram of the separate monosaccharides is shown in Figure 1.

\section{FRACTIONATION OF CRUDE FUCOIDAN}

Crude fucoidan (F0) was fractionated by DEAE-Sephadex A-25 to yield three fractions, F1, F2, and F3 (Figure 2). No polysaccharide was detected when using $3 \mathrm{M} \mathrm{NaCl}$ elution. All fractions contained fucose as the major sugar component followed by galactose, with small amounts of mannose, xylose, and glucose also present. However, the sugar composition varied among the three fractions (Table 1). The fractions were not sulfated xylogalactofucans like crude fucoidan, but were made up of sulfated galactofucans instead. The fraction eluted with a low $\mathrm{NaCl}$ concentration was higher in uronic acid and lower in sulfate content. Conversely, the fraction that was eluted with high $\mathrm{NaCl}$ concentration was higher in sulfate content and lower in uronic acid. This was similarly encountered with fucoidan from $S$. swartzii (31). The content of fucose increased significantly $(p<0.001)$ from F0 to F3 (Table 1), followed by a significant decrease in xylose content $(p<0.001)$. No noticeable changes between fractions were observed for galactose, mannose, and glucose. Protein content of the different fractions was also similar between F0, F2, and F3, but a significant decrease $(p=0.014)$ in protein content from F1 to F3 fractions indicated less protein contamination when using higher $\mathrm{NaCl}$ elution.

\section{MOLECULAR WEIGHT ESTIMATION OF FUCOIDAN BY GPC}

The average Mw of crude fucoidan from the sporophylls of New Zealand U. pinnatifida was estimated to be over $150 \mathrm{kDa}$ by GPC, after calibration with known standard Mw markers. The mass of crude fucoidan from New Zealand U. pinnatifida was higher than crude fucoidan from the sporophylls of the same species harvested 
Table 1 | Chemical composition of crude fucoidan (F0) from $U$. pinnatifida, its purified fractions (F1, F2, and F3) from farm 327 and commercial fucoidan (Sigma).

\begin{tabular}{|c|c|c|c|c|c|c|c|c|c|}
\hline Sample & Uronic acid (\%) & Sulphate (\%) & Protein $(\%)$ & Mw (kDa) & \multicolumn{5}{|c|}{ Monosaccharide composition (\%) } \\
\hline $\mathrm{F} 1$ & $4.34^{\mathrm{a}}$ & $6.96^{e}$ & $0.86^{a}$ & 81 & $48.51^{c}$ & $37.86^{a}$ & $3.74^{b}$ & $2.91^{a}$ & $6.97^{a}$ \\
\hline $\mathrm{F} 2$ & $0.84^{c}$ & $22.78^{b}$ & $0.63^{b}$ & 22 & $53.21^{b, c}$ & $42.12^{\mathrm{a}}$ & $1.15^{\mathrm{b}}$ & $1.28^{b}$ & $2.24^{\mathrm{C}}$ \\
\hline $\mathrm{F}$ & $0.67^{c}$ & $25.19^{a}$ & $0.11^{\mathrm{c}}$ & 27 & $59.71^{b}$ & $28.74^{b}$ & $1.58^{b}$ & $2.77^{a}$ & $7.19^{a}$ \\
\hline
\end{tabular}

${ }_{a, b, c, d, e}$ Column wise values with different superscripts indicate significant differences at $p<0.05$ by one-way ANOVA followed by the Tukey's post hoc comparison test.

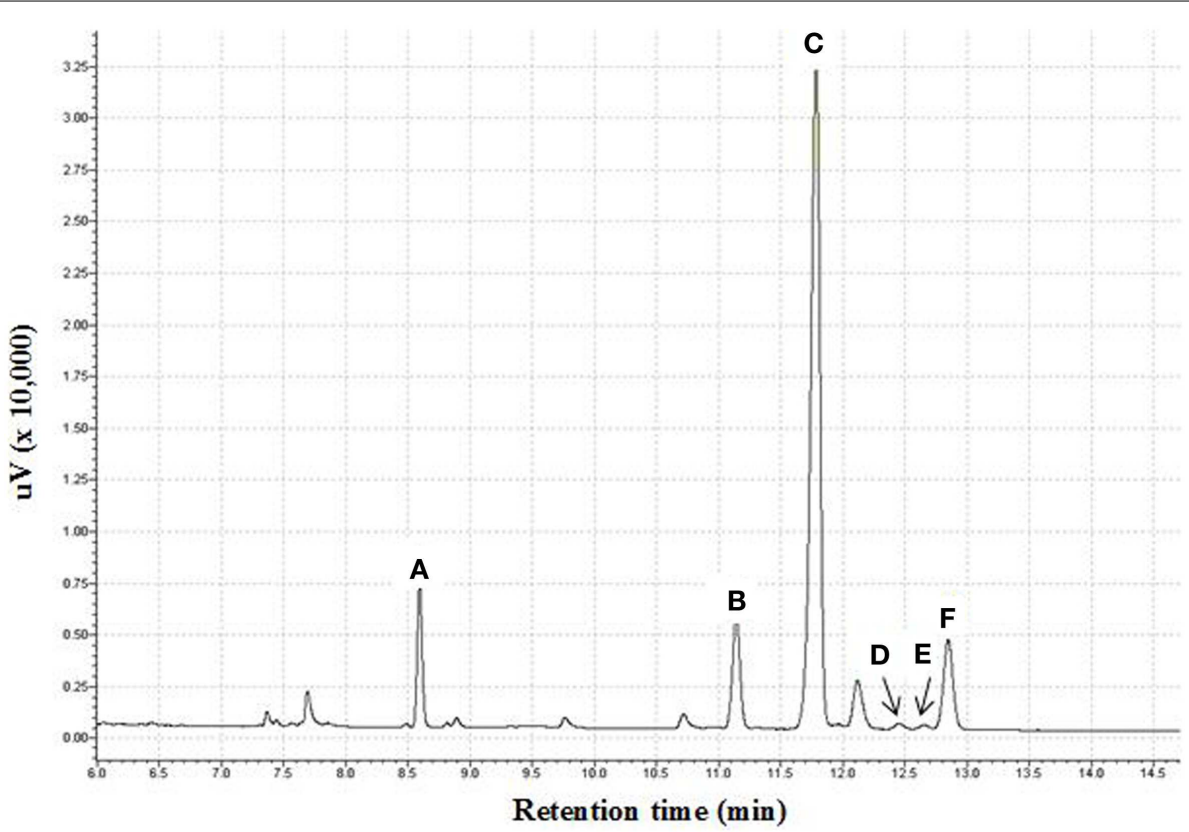

FIGURE 1 | Gas chromatogram of monosaccharide content of fucoidan obtained from $\boldsymbol{U}$. pinnatifida as alditol acetate derivatives. (A) Fucitol pentaacetate; (B) Xylitol pentaacetate; (C) Allitol hexaacetate; (D) Mannitol hexaacetate; (E) Galactitol hexaacetate; (F) Glucitol hexaacetate.

from Kijang, Korea that had a Mw of only $38 \mathrm{kDa}$ (32). Conversely, fucoidan extracted from the sporophylls of $U$. pinnatifida grown in Wando, Korea had a much higher average Mw of $2100 \mathrm{kDa}$ (6). The large differences in Mw from the same species were probably attributed to the different fucoidan extraction techniques used that may render fucoidan unstable when heating (33). Variation in Mw of fucoidans from $U$. pinnatifida was also reported by Fitton and Dragar (34). In this study, the Mw of fucoidan fractions eluted with water, 1 and $2 \mathrm{M} \mathrm{NaCl}$ were 81,22 , and $27 \mathrm{kDa}$, respectively (Table 1). The Mw of commercial fucoidan from $F$. vesiculosis purchased from Sigma was estimated to be $54 \mathrm{kDa}$, which was within the specified range obtained from the Sigma database of 20-200 kDa (35).

\section{CELL REDUCING CAPACITY OF FUCOIDAN ON CANCER CELL LINES}

Cell reducing capacity of crude (F0) and purified fucoidan fractions (F1 and F3) toward A-549 (lung carcinoma), WiDr (colon adenocarcinoma), MCF-7 (breast adenocarcinoma), Malme-3M (lung melanoma), and LoVo (human colon adenocarcinoma) cell lines were examined, and compared with commercial fucoidan from Sigma. Each cell line was treated with different concentrations of fucoidan $(0.2-1.0 \mathrm{mg} / \mathrm{mL})$ for 24,48 , and $72 \mathrm{~h}$ and assessed for cell viability using the MTT cell proliferation assay. This assay was based on the presence of mitochondrial dehydrogenase in viable cells to react with the yellow MTT to form a dark bluepurple formazan complex, which can be solubilized by the addition of DMSO. The amount of viable cells left remaining is directly proportional to the amount of formazan complex produced (36). The cell reducing capacity of fucoidan, expressed as the percentage of viable cells left remaining after fucoidan treatment on MCF-7, A549, WiDr, Malme-3M, and LoVo cell lines, is shown in Figure 3, while the $\mathrm{IC}_{50}$ values (the half minimal inhibitory concentration of a substance) are shown in Table 2. F2 was not included in the cytotoxicity test since this was the smallest of the three purified 


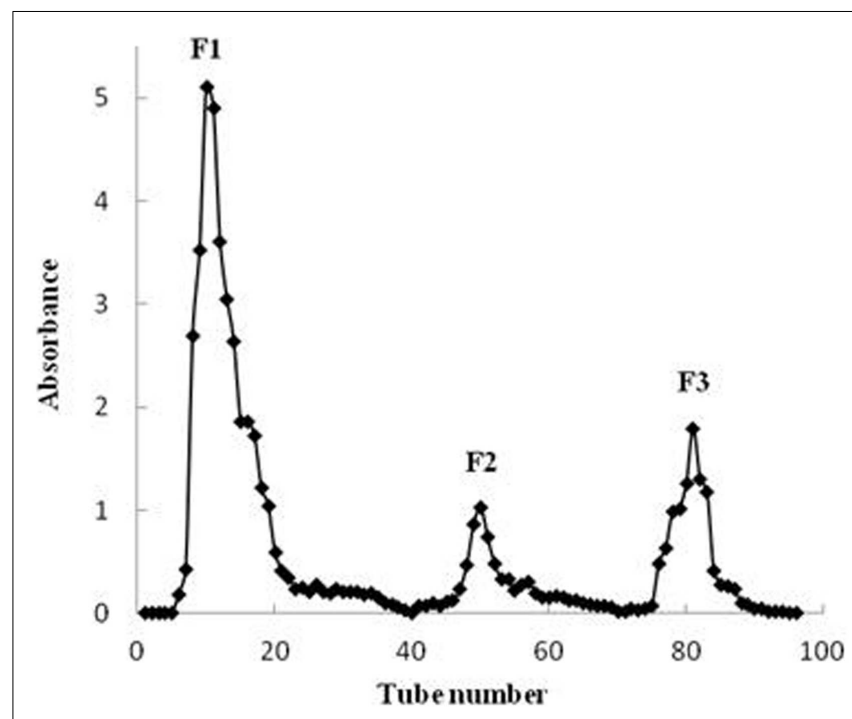

FIGURE 2 | Chromatogram of purified crude fucoidan extracts obtained from $U$. pinnatifida separated on a DEAE-Sephadex A-25 column.

fractions and was difficult to obtain sufficient amounts required for the MTT assay.

As shown in Figure 3, treatment of A-549 (A), MCF-7 (B), WiDr (C), LoVo (G), and Malme-3M (H) cell lines with all fucoidan samples showed a dose-dependent and time-dependent relationship at the concentrations $(0.2-1.0 \mathrm{mg} / \mathrm{mL})$ tested. The $\mathrm{IC}_{50}$ values of crude fucoidan (F0) from this study indicated a higher cytotoxicity than purified fractions (F1 and F3) and commercial fucoidan against both the MCF-7 breast cancer cells and A-549 lung cancer cells after $72 \mathrm{~h}$ cultivation (Table 2 ). At concentrations from 0.2 to $1.0 \mathrm{mg} / \mathrm{mL}, \mathrm{F} 0$ inhibited the development of cancer cells in a strong dose-dependent relationship and had cell viabilities that ranged from 52.1 to $0.4 \%$ against A-549 cells and $12.4-1.7 \%$ against MCF-7 cells after $72 \mathrm{~h}$ incubation. Moreover, F1 and F3 purified fractions had lower $\mathrm{IC}_{50}$ values indicating higher cell reducing capacity than commercial fucoidan when subjected to A-549 cells, while commercial fucoidan showed less cell reducing capacity than F0 and F3 when applied to MCF-7 cells. Conversely, commercial fucoidan exhibited the strongest cell reducing capacity against WiDr colon cancer cells than F0, F1, and F3 with $\mathrm{IC}_{50}$ values of $0.069,0.121$, and $0.072 \mathrm{mg} / \mathrm{mL}$, respectively after $72 \mathrm{~h}$ incubation. The fact that commercial fucoidan had stronger cell reducing capacity than $\mathrm{F} 0, \mathrm{~F} 1$, and $\mathrm{F} 3$ although its sulfate content is lower than F3 could be explained by the low Mw and high uronic acid content which both also increase the cell reducing capacity potential of fucoidans (31).

Considerable variations in cell reducing capacity were encountered for both crude fucoidan and fucoidan fractions on different cell lines. Commercial fucoidan showing much higher inhibitory action on WiDr cells than on MCF-7, A-549, Malme-3M, and LoVo cells $(p<0.001)$. Similarly, F1 and F3 fucoidan fractions had lower $\mathrm{IC}_{50}$ values for WiDr cells that were associated with a higher inhibitory action than the MCF-7 and A-549 cells. These results reported for the first time that the WiDr colon cancer cells were more susceptible to the inhibitory action of fucoidan compared to the MCF-7 and A-549 cells. A previous study reported that commercial fucoidan from F. vesiculosis (Sigma, USA) inhibited the growth of HT-29 colon cancer cells (14), a derivative of the WiDr colon cancer cells (37).

A trend was observed where crude fucoidan exhibited stronger cell reducing capacity than its lower Mw fractions for MCF-7, A-549, and WiDr cell lines. This finding was consistent with the results from a previous study, which reported a stronger inhibitory action of crude fucoidan from Utricularia aurea compared to its purified fractions on KB nasopharynx cancer cells (38). Although it has been suggested that fucoidans with a lower Mw and higher sulfate content would provide stronger cell reducing capacity (1, 19), results from this study showed otherwise. This is due to the fact that crude fucoidan in this study, which had the highest $\mathrm{Mw}$ of over $150 \mathrm{kDa}$ and a lower sulfate content than the purified fraction F3 (Table 1) exhibited the highest cell reducing capacity. This could be attributed to structural changes during the fractionation process such as depolymerization or by other features in crude fucoidan that may have cell reducing capacity effects (38) that may include the high amount of xylose present in crude fucoidan. Xylose has been used in the past as a component in the development of anticancer drugs (39), and thus there is a reason to believe that xylose content in crude fucoidan may play a vital role in the cell reducing capacity of fucoidans.

\section{CELL REDUCING CAPACITY OF FUCOIDAN ON NON-CANCER CELL LINES}

Although the cell reducing capacity of fucoidan on certain cancer cells is effective, fucoidan's selectivity on whether or not to attack non-cancer cells still remains unclear and the mechanisms of how they inhibit tumor growth are still not entirely understood (7). To be able to determine whether the fucoidans in this study had any effect on non-cancer cell lines, assessment of the effects of fucoidan on HUVEC, HDFb, and HEK-293 cell lines were measured using the MTT assay. Cell reducing capacity effects of fucoidan on all three non-cancer cell lines showed a dose-dependent manner, with HUVEC being the most sensitive to crude fucoidan with a reduction of viable cells to $13.0 \%$ after $72 \mathrm{~h}$ incubation at a concentration of $1 \mathrm{mg} / \mathrm{mL}$ crude fucoidan (Figure 3). A drastic reduction in cell viability was encountered for commercial fucoidan from $78.1 \%$ cell viability down to $41.7 \%$ upon increasing the concentration from 0.2 to $0.6 \mathrm{mg} / \mathrm{mL}$ at $24 \mathrm{~h}$ incubation. A trend was also noted that F3 had significantly weaker cell reduction rates than F0 and $\mathrm{F} 1$ at $0.2-1.0 \mathrm{mg} / \mathrm{mL}$ dosage levels for $24 \mathrm{~h}(p<0.001)$, but no significant differences were observed between F0 and F1 at the same concentrations and incubation period $(p<0.001)$. Fucoidan also inhibited the growth of HEK-293 and HDFb cells in a dosedependent fashion. However the extent of inhibition, based on cell viability (Figure 3), was smaller than with the HUVEC cells. The treatment of HEK-293 cells with $1 \mathrm{mg} / \mathrm{mL}$ crude fucoidan for $72 \mathrm{~h}$ incubation had a $63.7 \%$ cell reduction whereas at the same concentration of crude fucoidan and incubation period, HDFb cells had a $79.8 \%$ cell reduction, both having a significantly lower cell reduction rate than with WiDr (96.22\%), MCF-7 (98.32\%), and A-549 (99.96\%) cancer cells. 


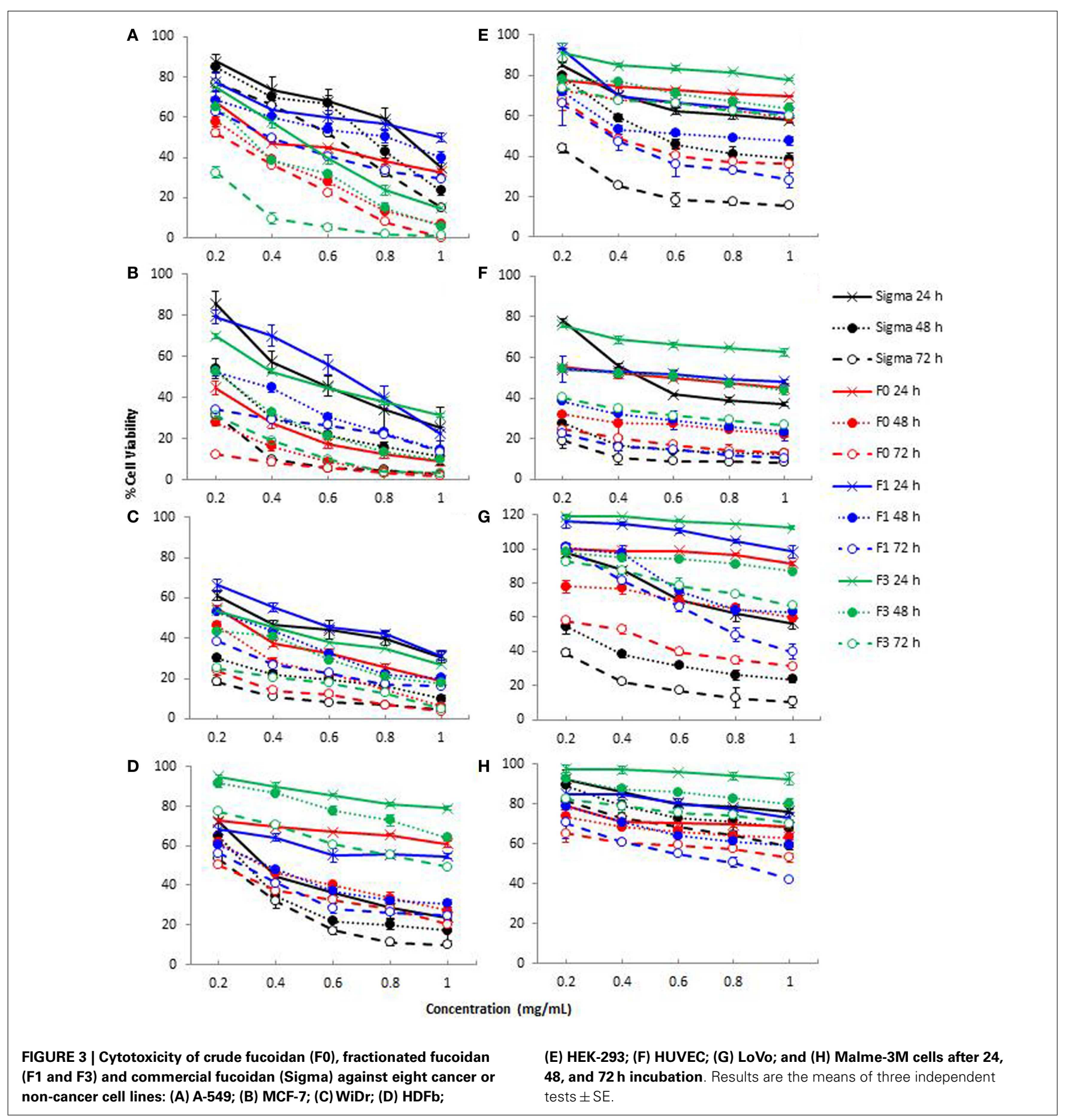

\section{DISCUSSION}

This is the first study to investigate fucoidan's composition and cytotoxicity extracted from New Zealand U. pinnatifida. Since fucoidan is a carbohydrate polymer mixture, fucoidans extracted from different seaweed or from same species but growing at different locations have different bioactivity, including in vitro cell reducing capacity in tumor cells (40). Hence, it is important to study fucoidan extracted from U. pinnatifida grown in New
Zealand to identify whether it has any unique characteristics and biological functions.

The sugar composition and sulfate content indicated that crude fucoidan isolated from the sporophylls of $U$. pinnatifida from New Zealand was made up of sulfated xylogalactofucans. Protein content of New Zealand fucoidan was much lower than in other fucoidans reported $(1,12,41)$. This indicated the effectiveness of the extraction technique used in this study to eliminate 
Table 2 | Effect of crude fucoidan (F0), its fractions (F1 and F3) and commercial fucoidan (Sigma) toward MCF-7, A-549, WiDr, Malme-3M, LoVo, HDFb, HUVEC, and HEK-293 cell lines at three different incubation times $(24,48$, and $72 \mathrm{~h})$.

\begin{tabular}{|c|c|c|c|c|c|c|}
\hline Cell line & Incubation period (h) & Cell type & $\mathbf{F O}^{\mathbf{b}}$ & $F 1^{b}$ & $\mathbf{F} 3^{\mathbf{b}}$ & Sigmab \\
\hline \multicolumn{7}{|l|}{ TUMOR $^{\mathrm{a}}$} \\
\hline \multirow[t]{3}{*}{ MCF-7 } & 24 & Breast adenocarcinoma & 0.173 & 0.651 & 0.405 & 0.515 \\
\hline & 48 & & 0.024 & 0.245 & 0.231 & 0.221 \\
\hline & 72 & & 0.010 & 0.148 & 0.110 & 0.134 \\
\hline \multirow[t]{3}{*}{ A-549 } & 24 & Lung carcinoma & 0.869 & 1.018 & 0.453 & 0.869 \\
\hline & 48 & & 0.278 & 0.675 & 0.315 & 0.744 \\
\hline & 72 & & 0.147 & 0.372 & 0.242 & 0.582 \\
\hline \multirow[t]{3}{*}{ WiDr } & 24 & Colon adenocarcinoma & 0.244 & 0.400 & 0.216 & 0.321 \\
\hline & 48 & & 0.146 & 0.220 & 0.173 & 0.072 \\
\hline & 72 & & 0.069 & 0.121 & 0.072 & 0.038 \\
\hline \multirow[t]{3}{*}{ Malme-3M } & 24 & Lung melanoma & $>50^{c}$ & $>70^{c}$ & $>140^{c}$ & $>80^{c}$ \\
\hline & 48 & & $>40^{c}$ & $>40^{c}$ & $>90^{C}$ & $>60^{c}$ \\
\hline & 72 & & $>30^{c}$ & $>30^{c}$ & $>60^{c}$ & $>50^{c}$ \\
\hline \multirow[t]{3}{*}{ LoVo } & 24 & Colon adenocarcinoma & 19.090 & $d$ & $d$ & 1.548 \\
\hline & 48 & & 1.358 & 2.044 & 7.596 & 0.264 \\
\hline & 72 & & 0.394 & 1.051 & 2.210 & 0.121 \\
\hline \multicolumn{7}{|c|}{ NON-TUMOR ${ }^{a}$} \\
\hline \multirow[t]{3}{*}{$\mathrm{HDFb}$} & 24 & Derma fibroblast & $>40^{c}$ & $>30^{c}$ & $>90^{c}$ & 18.132 \\
\hline & 48 & & 18.397 & 18.436 & $>70^{c}$ & 12.845 \\
\hline & 72 & & 13.532 & 14.542 & $>40^{c}$ & 9.745 \\
\hline \multirow[t]{3}{*}{ HUVEC } & 24 & Umbilical vein & 24.828 & 26.246 & $>40^{c}$ & 26.053 \\
\hline & 48 & & 10.108 & 11.604 & 24.794 & 7.142 \\
\hline & 72 & & 7.339 & 6.672 & 12.854 & 5.722 \\
\hline \multirow[t]{3}{*}{ HEK-293 } & 24 & Embryonic kidney & 0.0605 & 0.057 & 0.091 & $>40^{\mathrm{c}}$ \\
\hline & 48 & & 0.046 & 0.030 & 0.056 & 28.520 \\
\hline & 72 & & 0.022 & 0.019 & 0.046 & 9.523 \\
\hline
\end{tabular}

${ }^{a} / C_{50}(\mathrm{mg} / \mathrm{mL})$ was evaluated by the MTT assay, as reported in Section "Cell reducing capacity (cytotoxicity) assay."

${ }^{b}$ Results are the mean of three independent experiments.

'Values are extrapolated.

${ }^{\circ}$ Not determined.

Results are expressed as $1 C_{50}(\mathrm{mg} / \mathrm{mL})$.

protein contamination (41). Negatively charged sulfate and uronic acid components of crude fucoidan were more or less lower than fucoidan extracted from S. swartzii (31) and Laminaria japonica (12). Fucose content in crude fucoidan was somewhat lower than fucoidans extracted from $U$. pinnatifida in Korea $(19,21)$. However, using different fucoidan extraction methods, galactose and xylose content of fucoidan from New Zealand $U$. pinnatifida were much higher than Korean fucoidan indicating that monosaccharide variations exist within the same species grown in different countries. At present, no reports have reported about xylogalactofucans being extracted from U. pinnatifida but there have been reports for other species including L. angustata (42), Sphacelaria indica (43), and Spatoglossum schroederi (44). Fucose content from commercial fucoidan derived from $F$. vesiculosus was significantly higher $(p<0.001)$ than our crude fucoidan. However, xylose, galactose, and mannose content were significantly lower in commercial fucoidan compared to crude fucoidan (Table 1). Variations in fucoidan yield and chemical composition was possibly attributed to the difference in fucoidan extraction techniques, alga harvest season, harvest location, degree of alga maturation, and alga species $(3,32,45)$.

A decrease in Mw was observed from F0 to F3 fucoidan fractions as $\mathrm{NaCl}$ concentration increased. This change in Mw pattern was also observed with fucoidan extracted from U. pinnatifida grown in Peter the Great Bay, using a DEAE-Sephadex A-25 column (3). The decrease in $\mathrm{Mw}$ of the fractions was assumed to be caused by depolymerization of fucoidan during the fractionation process (9). In the present work, purified fucoidan fractions from New Zealand U. pinnatifida harvested in the Marlborough Sounds, New Zealand was found to be sulfated galactofucans with high $\mathrm{Mw}$. These results also showed that crude fucoidan from New Zealand U. pinnatifida were heterogeneous in terms of its sulfate content, uronic acid content, and monosaccharide composition. This is supported by previous studies that have also reported fucoidan from S. swartzii, Pelvetia canaliculata, $F$. vesiculosus, S. muticum, and L. digitata as being heterogeneous $(31,46)$.

The cytotoxicity findings in this study confirmed that crude fucoidan had strong cell reducing capacity, as reported by other 
studies, using fucoidan from the sporophylls of $U$. pinnatifida (1, 16). The cell reducing capacity of crude fucoidan on MCF-7 cells over $48 \mathrm{~h}$ was considerably higher than fucoidan polymers from A. nodosum harvested from Ireland, which showed no significant decrease in viable cell numbers over $48 \mathrm{~h}$ (47). Similarly, when fucoidan purchased from the NPO Research Institute of Fucoidan, Japan was tested, the number of MCF-7 cells after $48 \mathrm{~h}$ incubation increased from approximately $15 \times 10^{4}$ to $18 \times 10^{4}$ cells/well, meaning there was no inhibition of MCF-7 cells. However, a significant decrease in viable cell numbers was only achieved after $96 \mathrm{~h}$ incubation period (48). In this study, the degree of inhibition of crude fucoidan on MCF-7 cells was much higher; with only $2.6 \%$ viable cells left remaining after $48 \mathrm{~h}$. The results also showed that fucoidan reacted differently to the cell type used, with A549 cells less sensitive to fucoidans, thereby having a higher $\mathrm{IC}_{50}$ value compared to MCF-7 and WiDr cells (Table 2). Fucoidan from the sporophylls of U. pinnatifida from South Korea inhibited the growth of A-549 cells from 85.1 to $62.4 \%$ at concentrations from 0.2 to $1.0 \mathrm{mg} / \mathrm{mL}$ (19). The degree of A-549 inhibition was, however, higher in this study, with $67.5-32.7 \%$ inhibition at concentrations from 0.2 to $1.0 \mathrm{mg} / \mathrm{mL}$ after $24 \mathrm{~h}$ incubation with crude fucoidan. In addition, cell reducing capacity of crude fucoidan from the sporophylls of Korean U. pinnatifida against A-549 cells was much lower than crude fucoidan from this study when comparisons were made between the cell viability graphs obtained from their study and ours (16). This confirmed that fucoidan polymers from the same species may result in different cell proliferation capacities that could be due to differences in structural properties and cell type procedures (38).

The results also revealed that fucoidan inhibited dosedependently of LoVo and Malme-3M cells, although the level of cell reducing capacity was much less than what was encountered with A-549, WiDr, and MCF-7. All fucoidan fractions (F0, F1, and F3) after incubation for $24 \mathrm{~h}$ showed significantly less inhibition of LoVo cells when compared to A-549, MCF-7, and WiDr cells at the same incubation period $(p<0.001)$. Commercial fucoidan showed the strongest effect of suppression for LoVo cells at 24, 48 , and $72 \mathrm{~h}$ incubation than all fucoidan fractions, and showed a lower $\mathrm{IC}_{50}$ value than A-549 at 48 and $72 \mathrm{~h}$ incubation (Table 2). Both WiDr and LoVo cells are derived from the same tissue region (colon adenocarcinoma) yet the supplementation of both these cells with fucoidan resulted in dissimilar decreases in cell growth capacity (Figure 3). Incubation of WiDr and LoVo cell lines with fucoidan both resulted in dose-dependent decreases in cell growth capacity, with the greatest decreases observed in WiDr cells. It was suggested that the amount of suppression in cell lines of different fucoidans were peculiar and its effects on different kind of cancer cells was different (49). One factor which we believe may have been associated with the differences in inhibiting potential of fucoidan on LoVo and WiDr cells could be the type of grade of the cancer cells, LoVo cells being an advanced bowel cancer type whereas WiDr cells are not. Although no previous studies have indicated this, it is possible that the grade of cell carcinoma could be a factor in fucoidan's inhibiting potential.

A pattern was also observed for the purified fucoidan fractions, where a decrease in $\mathrm{IC}_{50}$ values (Table 2) was evident from fractions $\mathrm{F} 1$ to $\mathrm{F} 3$, indicating an increase in cell reducing capacity for
WiDr, MCF-7, and A-549 cancer cell lines. In addition, it appears that the lower the Mw of the purified fucoidan fraction, the higher the cell reducing capacity. Low Mw and high uronic acid content can increase the cell reducing capacity potential of fucoidans (31). Several studies have confirmed the same effect of having low Mw and high uronic acid content in fucoidans on A-549 and gastric carcinoma cell lines $(1,19)$. In addition, a significant increase $(p<0.001)$ in sulfate content was encountered from fractions F1 $(6.96 \%)$ to $\mathrm{F} 3(25.19 \%)$. Studies $(11,19,50)$ have indicated that sulfate groups play a major role in the inhibition of cancer cells that may further aid in the suppression of cancer cells. The mechanism by which low Mw-fucoidan polymers result in cytotoxicity has yet to be ascertained. Assumptions have been made that the large Mw-fucoidans have a better chance of having a compact spherical conformation, while low Mw-fucoidans are more likely to exist in a loosed and linear form (1). As anionic sulfate groups may be hidden inside the spherical conformation of a large Mw-fucoidan polymer, this leads to a decrease in the sulfate groups allowed to react with the cancer cells. Therefore, in this study, the observed increase in cell reducing capacity from F1 to F3 may be linked to a combination of a lower Mw and increased sulfate content of the F3 fraction.

Fucoidan from this study had similar effects to commercial fucoidan against non-cancer cell lines, although commercial fucoidan had stronger effects than all fucoidan fractions when administered to HUVEC cells at $1 \mathrm{mg} / \mathrm{mL}$ fucoidan for $72 \mathrm{~h}$. Similar studies also reported that fucoidan from U. pinnatifida inhibited cell proliferation of HUVEC cultures which in turn may have potential in the prevention of angiogenesis-related diseases (51, 52). From observing Figure 3, commercial fucoidan appeared to have a stronger cell reducing capacity rate than all fucoidan fractions toward HEK-293 and HDFb cells which showed as high as 84.3 and $90.2 \%$ inhibition activity at $1 \mathrm{mg} / \mathrm{mL}$ dosage level, respectively. Conversely, F3 was the less potent at $24 \mathrm{~h}$ incubation for all three normal cell lines, most likely due to its low Mw of only $27 \mathrm{kDa}$.

In conclusion, crude fucoidan isolated from New Zealand $U$. pinnatifida was a sulfated-xylogalactofucan. It was made up of predominantly fucose, galactose, xylose, and sulfate, which exist along with mannose, glucose, uronic acid, and protein as minor constituents. The results from this study showed that sporophyllderived fucoidan from New Zealand $U$. pinnatifida had cell reducing capacity effects against MCF-7, A-549, and WiDr cells that was comparable with commercial fucoidan from $F$. vesiculosis. The Mw and degree of sulfation appeared to be related to the cytotoxicity of purified fucoidan fractions. Fucoidan content is high in the sporophyll of New Zealand U. pinnatifida which is normally regarded as waste and would therefore be beneficial to derive fucoidan from the sporophyll of this alga. Since fucoidan has the potential to reducing cancer cell growth, the sporophyll of New Zealand $U$. pinnatifida can be a good resource for manufacturing health products or produce food for health. The results have also shown that extracted fucoidan exerts cell reducing capacity effects in a variety of cancer cells. Even though it has toxicity at high concentration, it exhibits anti-proliferation effect in cancer cells at concentration lower than the normal cell toxic level. We believe it is possible to be used to combine with other chemotherapeutic agents to treat 
cancer. Therefore, further studies on fucoidan extracted from New Zealand U. pinnatifida are warranted, possibly in animal or clinical trials.

\section{ACKNOWLEDGMENTS}

This study was financially supported by the School of Applied Sciences, and Faculty of Health and Environmental Sciences, Auckland University of Technology. We are thankful to Wakatu Incorporation for their contribution in harvesting $U$. pinnatifida from their mussel farms.

\section{REFERENCES}

1. You SG, Yang C, Lee HY, Lee BY. Molecular characteristics of partially hydrolyzed fucoidans from sporophyll of Undaria Pinnatifida and their in vitro anticancer activity. Food Chem (2010) 119:554-9. doi:10.1016/j.foodchem.2009.06.054

2. Kloareg B, Quatrano RS. Structure of the cell walls of marine algae and ecophysiological functions of the matrix polysaccharides. Oceanogr Mar Biol Ann $\operatorname{Rev}(1988)$ 26:259-315.

3. Skriptsova AV, Shevchenko NM, Zvyagintseva TN, Imbs TI. Monthly changes in the content and monosaccharide composition of fucoidan from Undaria pinnatifida (laminariales, phaeophyta). JAppl Phycol (2009) 22:79-86. doi:10.1007/ s10811-009-9438-5

4. Kylin K. Biochemie der Meeresalgen. HoppeSeyler's Z Physiol Chem (1913) 83:171-97. doi:10.1515/bchm2.1913.83.3.171

5. Zvyagintseva TN, Shevchenko NM, Chizhov AO, Krupnova TN, Sundukova EV, Isakov VV. Water-soluble polysaccharides of some far-eastern brown seaweeds. Distribution, structure, and their dependence on the development conditions. J Exp Mar Bio Ecol (2003) 294:1-13. doi:10.1016/S0022-0981(03)00244-2

6. Kim WJ, Kim SM, Kim HG, Oh HR, Lee KB, Lee YK, et al. Purification and anticoagulant activity of a fucoidan from Korean Undaria pinnatifida sporophyll. Algae (2007) 22:247-52. doi:10.4490/ALGAE.2007.22.3.247

7. Li B, Lu F, Wei X, Zhao R. Fucoidan: structure and bioactivity. Molecules (2008) 13:1671-95. doi:10.3390/molecules13081671

8. Park HY, Han MH, Park C, Jin CY, Kim GY, Choi IW, et al. Anti-inflammatory effects of fucoidan through inhibition of NF-кB, MAPK and Akt activation in lipopolysaccharide-induced BV2 microglia cells. Food Chem Toxicol (2011) 49:1745-52. doi:10.1016/j.fct.2011.04.020

9. Hemmingson JA, Falshaw R, Furneaux RH, Thompson K. Structure and antiviral activity of the galactofucan sulfates extracted from Undaria pinnatifida (phaeophyta). J Appl Phycol (2006) 18:185-93. doi:10.1007/s10811-006-9096-9

10. Ngo DH, Wijesekara I, Vo TS, Ta QV, Kim SK. Marine food-derived functional ingredients as potential antioxidants in the food industry: an overview. Food Res Intern (2011) 44:523-9. doi:10.1016/j.foodres.2010.12.030

11. Cho ML, Lee BY, You SG. Relationship between oversulfation and conformation of low and high molecular weight fucoidans and evaluation of their in vitro anticancer activity. Molecules (2011) 16:291-7. doi:10.3390/molecules16010291

12. Wang J, Zhang Q, Zhang Z, Li Z. Antioxidant activity of sulphated polysaccharide fractions extracted from Laminaria japonica. Int J Biol Macromol (2007) 42:127-32. doi:10.1016/j.ijbiomac.2007.10.003

13. Bilan MI, Grachev AA, Ustuzhanina NE, Shashkov AS, Nifantiev NE, Usov AI. Structure of fucoidan from the brown seaweed Fucus evanescens. Carbohydr Res (2002) 337:719-30. doi:10.1016/S0008-6215(02)00053-8

14. Kim EJ, Park SY, Lee JY, Park JH. Fucoidan present in brown algae induces apoptosis of human colon cancer cells. BMC Gastroenterol (2010) 10:96. doi:10.1186/1471-230X-10-96

15. Ye J, Li Y, Teruya K, Katakura Y, Ichikawa A, Eto H. Enzyme-digested fucoidan extracts derived from seaweed Mozuku of Claosiphon novae-caldoniae kylin inhibit invasion and angiogenesis of tumor cells. Cytotechnology (2005) 47:117-26. doi:10.1007/s10616-005-3761-8

16. Synytsya A, Kim WJ, Kim SM, Pohl R, Synytsya A, Kvasnicka F, et al. Structure and antitumor activity of fucoidan isolated from sporophyll of Korean brown seaweed Undaria pinnatifida. Carbohydr Polym (2010) 81:41-8. doi:10.1016/j. carbpol.2010.01.052

17. Ale MT, Mikkelsen JD, Meyer AS. Important determinants for fucoidan bioactivity: a critical review of structure-function relations and extraction methods for fucose-containing sulfated polysaccharides from brown seaweeds. Mar Drugs (2011) 9:2106-30. doi:10.3390/md9102106
18. Irhimeh MR. A quantitative method to detect fucoidan in human plasma using a novel antibody. Methods Find Exp Clin Pharmacol (2005) 27:705-10. doi:10.1358/mf.2005.27.10.948919

19. Yang C, Chung D, Shin S, Lee HY, Kim JC, Lee YJ, et al. Effects of molecular weight and hydrolysis conditions on anticancer activity of fucoidans from sporophyll of Undaria pinnatifida. Int J Biol Macromol (2008) 43:433-7. doi:10.1016/j.ijbiomac.2008.08.006

20. Stuart MD. Review of Research on Undaria pinnatifida in New Zealand and its Potential Impacts on the Eastern Coast of the South Island. Wellington: Department of Conservation (2004). DOC Science Internal Series.

21. Lee YK, Lim D, Lee Y, Park Y. Variation in fucoidan contents and monosacharide compositions of Korean Undaria pinnatifida (Harvey) Suringar (phaeophyta). Algae (2006) 21:157-60. doi:10.4490/ALGAE.2006.21.1.157

22. Fung A, Hamid N, Lu J. Fucoxanthin content and antioixdant properties of Undaria pinnatifida. Food Chem (2013) 136:1055-62. doi:10.1016/j.foodchem. 2012.09.024

23. Mak W, Hamid N, Liu T, Lu J, White WL. Fucoidan from New Zealand Undaria pinnatifida: monthly variations and determination of antioxidant activities. Carbohydr Polym (2013) 95:606-14. doi:10.1016/j.carbpol.2013. 02.047

24. Dodgson KS, Price RG. A note on the determination of the ester sulphate content of sulphated polysaccharides. Biochemistry (1962) 84:106-10.

25. Bitter T, Muir HM. A modified uronic acid carbazole reaction. Anal Biochem (1962) 4:330-4. doi:10.1016/0003-2697(62)90095-7

26. Bradford MM. A rapid and sensitive for the quantitation of microgram quantities of protein utilizing the principle of protein-dye binding. Anal Biochem (1976) 72:248-54. doi:10.1016/0003-2697(76)90527-3

27. Dubois M, Gilles KA, Hamilton JK, Rebers PA, Smith F. Colorimeter method for determination of sugars and related substances. Anal Chem (1956) 28:350-6. doi:10.1021/ac60111a017

28. Melton LD, Smith BG. Determination of neutral sugars by gas chromatography of their alditol acetates. Curr Protoc Food Anal Chem (2001) 2001:E3.2.1-3.2.13. doi:10.1002/0471142913.fae0302s00

29. Freshney RI. Culture of Animal Cells: A Manual of Basic Technique. New York: Wiley-Liss Inc (1994).

30. Eluvakkal T, Sivakumar SR, Arunkumar K. Fucoidan in some Indian brown seaweeds found along the Coast Gulf of Mannar. Int J Botany (2010) 6:176-81. doi:10.3923/ijb.2010.176.181

31. Ly BM, Buu NQ, Nhut ND, Thinh PD, Van TTT. Studies on fucoidan and its production from Vietnamese brown seaweeds. Asean J Sci Technol Dev (2005) 22:371-80. doi:10.3125/asean.v22i4.395

32. Koo JG, Jo KS, Do JR, Woo SJ. Isolation and purification of fucoidans from Laminaria religiosa and Undaria pinnatifida in Korea. J Korean Fish Soc (1995) 28:227-36.

33. Sakai T, Ishizuka K, Kato I. Isolation and characterization of a fucoidandegrading marine bacterium. J Mar Biotechnol (2003) 5:70-8. doi:10.1007/ s10126-002-0056-3

34. Fitton HJ, Dragar C. Method and Composition for the Treatment of a Viral Infection. (2006) Marinova Party Limited, U.S. Patent 7056520 B2.

35. Sigma-Aldrich. Fucoidan from Fucus Vesiculosus [Online]. Product Specification Sheet. Sigma-Aldrich (2011).

36. Nursid M, Fajarningsih ND, Wikanta T. Isolation of cytotoxic compound from Nepthea sp. soft coral. J Biotech Res Trop Region (2009) 2(1):1-5 (Special edition).

37. Chen T, Drabkowski D, Hay R, Macy M, Peterson W. WiDr is a derivative of another colon adenocarcinoma cell line, HT-29. Cancer Genet Cytogenet (1987) 27:125-34. doi:10.1016/0165-4608(87)90267-6

38. Choosawad D, Leggat U, Dechsukhum C, Phongdara A, Chotigeat W. Antitumour activities of fucoidan from the aquatic plant Utricularia aurea lour. J Sci Technol (2005) 27(Suppl 3):799-807.

39. Nobuhiko S, Chiyokichi L, Hiroaki M. Anticancer Drugs. (1984). US Patent No. $4,461,760$.

40. Vishchuk OS, Ermakova SP, Zvyagintseva TN. The fucoidans from brown algae of far-eastern seas: antitumor activity and structure-function relationship. Food Chem (2013) 141:1211-7. doi:10.1016/j.foodchem.2013.03.065

41. Ponce NMA, Pujol CA, Damonte EB. Fucoidans from the brown seaweed Adenocystis utricularis: extraction methods, antiviral activity and structural studies. Carbohydr Res (2003) 338:153-65. doi:10.1016/S0008-6215(02) 00403-2 
42. Saha S, Navid MH, Bandyopadhyay SS, Schnitzler P, Ray B. Sulfated polysaccharides from Laminaria angustata: structural features and in vitro antiviral activities. Carbohydr Polym (2012) 87:123-30. doi:10.1016/j.carbpol. 2011.07.026

43. Bandyopadhyay SS, Navid MH, Ghosh T, Schnitzler P, Ray B. Structural features and in vitro antiviral activities of sulfated polysaccharides from Sphacelaria indica. Phytochemistry (2011) 72:276-83. doi:10.1016/j.phytochem. 2010.11.006

44. Guerra CM, De Abreu LD, Nader HB, Leite EL. A xylogalactofucan from the brown seaweed Spatoglossum schroederi stimulates the synthesis of an antithrombotic heparan sulfate from endothelial cells. Planta Med (2005) 71:379-81. doi:10.1055/s-2005-864110

45. Vishchuk OS, Ermakova SP, Zvyagintseva TN. Sulfated polysaccharides from brown seaweeds Saccharina japonica and Undaria pinnatifida: isolation, structural characteristics, and antitumor activity. Carbohydr Res (2011) 346:2769-76. doi:10.1016/j.carres.2011.09.034

46. Mabeau S, Kloareg B, Joseleau JP. Fractionation and analysis of fucans from brown algae. Phytochemistry (1990) 29:2441-5. doi:10.1016/0031-9422(90) 85163-A

47. Foley SA, Szegezdi E, Mulloy B, Samali A, Tuohy MG. An unfractionated fucoidan from Ascophyllum nodosum: extraction, characterization, and apoptotic effects in vitro. J Nat Prod (2011) 74:1851-61. doi:10.1021/np200124m

48. Yamasaki-Miyamoto Y, Yamasaki MHT, Yamada K. Fucoidan induces apoptosis through activation of caspase- 8 on human breast cancer. J Agric Food Chem (2009) 57:8677-82. doi:10.1021/jf9010406

49. Tachikawa D, Maemura M, Fujii M. Anticancer Effect of Fucoidan Based on Biological and Clinical Study. Kagoshima: Kagoshima University (2005).
50. Kawamoto H, Miki Y, Kimura T, Tanaka K, Nakagawa T, Kawamukai M, et al. Effects of Fucoidan from mozuku on human cell lines. Food Sci Technol Resour (2006) 12:218-22. doi:10.3136/fstr.12.218

51. Cumashi A, Ushakova NA, Preobrazhenskaya ME, D’Incecco A, Piccoli A, Totani L, et al. A comparative study of the anti-inflammatory, anticoagulant, antiangiogenic, and antiadhesive activities of nine different fucoidans from brown seaweeds. Glycobiology (2007) 17:541-52. doi:10.1093/glycob/cwm014

52. Liu F, Wang J, Chang AK, Liu B, Yang L, Li Q, et al. Fucoidan extract derived from Undaria pinnatifida inhibits angiogenesis by human umbilical vein endothelial cells. Phytomedicine (2012) 19:797-803. doi:10.1016/j.phymed.2012.03.015

Conflict of Interest Statement: The authors declare that the research was conducted in the absence of any commercial or financial relationships that could be construed as a potential conflict of interest.

Received: 22 March 2014; accepted: 26 June 2014; published online: 10 July 2014. Citation: Mak W, Wang SK, Liu T, Hamid N, Li Y, Lu J and White WL (2014) Anti-proliferation potential and content of fucoidan extracted from sporophyll of New Zealand Undaria pinnatifida. Front. Nutr. 1:9. doi: 10.3389/fnut.2014.00009

This article was submitted to Nutrition and Food Science Technology, a section of the journal Frontiers in Nutrition.

Copyright (C) 2014 Mak, Wang, Liu, Hamid, Li, Lu and White. This is an open-access article distributed under the terms of the Creative Commons Attribution License (CC $B Y)$. The use, distribution or reproduction in other forums is permitted, provided the original author(s) or licensor are credited and that the original publication in this journal is cited, in accordance with accepted academic practice. No use, distribution or reproduction is permitted which does not comply with these terms. 